\title{
Fim do milênio mistura terror e utopia
}

\author{
Antônio Araújo
}

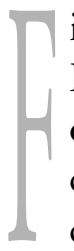

im dos tempos ou começo de uma nova era? Este final de milênio parece conter ambos os comportamentos: o temor da aniquilação total e a utopia de uma nova civilização. Daí o interesse em investigar esta zona de tensão e ansiedade em que vivemos, em todas as suas contradições.

Não acredito em transformações milagrosas nem em recompensa dos Eleitos. Mas me intriga essa idéia de um Julgamento Final, de uma punição final e todos os temores por eles provocados. E é curioso que se tal idéia instiga o desejo e a urgência por uma purificação e conseqüente salvação, ao mesmo tempo, vê-se uma crescente onda de barbarismo e violência. Atos terroristas, crimes em massa, guerras étnicas estão na ordem do dia.

E guardo até hoje o sentimento de perplexidade e horror quando li, numa banca de jornais, sobre a "queima" do índio pataxó em Brasília por um grupo de jovens de classe média. A violência gratuita, sem causa e justificativa, lança-nos na região do absolutamente incompreensível e confronta-nos com a questão do Mal. Decadência de valores? Manifestações da Besta Apocalíptica? Ou simplesmente traços característicos, ainda que indesejáveis, da condição humana?
A crença no fim dos tempos parece dizer respeito não apenas à ansiedade provocada por uma data numérica no calendário, mas também a essa nossa própria condição. Aqui, os horizontes individuais e coletivos se interceptam. À percepção subjetiva da passagem do tempo, do envelhecimento e morte que cada um de nós vivencia, mistura-se um sentimento coletivo, uma consciência universal sobre o confronto com a Morte e a transitoriedade. Um final de milênio parece nada mais fazer do que intensificar e ampliar essas percepçôes.

Vivo sentimentos confusos em relação ao próximo século. Não me sinto totalmente confiante em relação ao futuro, mas resisto a acreditar em profecias de destruição. Nem Nova Jerusalém, por um lado, nem Queda da Babilônia por outro. Espero, na verdade, que possamos, com essa pesquisa, mais do que pintar quadros de salvação ou destruição, questionar e refletir sobre a dialética de esperança e temor, presente nos últimos anos deste nosso findante milênio. E o que talvez esse trabalho proponha seja, de fato, um mergulho nesta época de confusão e crise, nesse tempo de transição e, em última instância, um confronto com a inevitabilidade dos nossos próprios apocalipses pessoais.

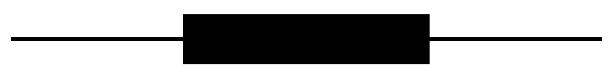

Antônio Araújo é professor do Departamento de Artes Cênicas da ECA-USP e encenador. 